\title{
Constraints Faced by Dairy Owners in Adoption of Marketing and Scientific Dairy Practices in Haryana
}

\author{
Jagdish Kumar ${ }^{1}$, Nirmal Kumar², Baskaur ${ }^{3}$, Raj Kumar ${ }^{4}$ and Vinay Kumar \\ ${ }^{1}$ Singhania University, Pacheri Bari, Jhunjhunu, Rajasthan, India \\ ${ }^{2}$ Department of Agricultural Economics, CCS Haryana Agricultural University, Hisar, India \\ ${ }^{3}$ Department of Sociology, CCS Haryana Agricultural University, Hisar, India \\ ${ }^{4}$ Department of Agricultural Economics, College of Horticulture, Maharana Pratap Horticultural University, Karnal, Haryana, India \\ ${ }^{5}$ Department of Business Management, CCS Haryana Agricultural University, Hisar, India
}

*Corresponding author: nkkalirana@gmail.com (ORCID ID: 0000-0002-9242-7110)

Received: $27-08-2021$

Revised: 21-11-2021

Accepted: 02-12-2021

\begin{abstract}
The present study was conducted in Sirsa and Hisar districts of Haryana state with the objective to find the constraints faced by dairy owners on adoption of marketing and scientific dairy practices. The multistage stratified random sampling technique was used for selection of the respondents. It was revealed from the study conducted in Sirsa and Hisar districts of Haryana that farmers of Sirsa perceived constraints regarding feeding practices most seriously and with higher concentration as compared to the farmers of Hisar districts which may be due to significant difference of agro-climatic variation as well as lack of large sized processing industries in Hisar district as compared to such industries in Sirsa district. All the farmers' across different categories reported lack of veterinary clinics and medical stores and high cost of treatment as serious constraints thus underlining the immediate need of low cost and highly accessible treatment. Uniform application of technology or adoption of umbrella approach for extension appears difficult given the observed differences in awareness and adoption. Future research and technology generation should, therefore, identify the differential technological requirements of different categories of farmers and should deliver technologies appropriate to needs of farmers. Shift to farming systems research and participatory technology development are suggested.
\end{abstract}

\section{HIGHLIGHTS}

0 Almost all the farmers across different categories considered high cost of treatment as serious constraints in adoption of marketing and scientific dairy farming practices thus underlining the need to develop low cost treatment regimens.

(0 Problems of repeat breeding and high charges for A.I facility as most serious constraints in Sirsa and Hisar districts, respectively.

Keywords: Cattle, buffalo, husbandry practices, feeding, management, institutional and marketing constraints

Animal husbandry in India is closely interwoven with agriculture and plays an important part in the rural economy. But it did not receive as much attention as crop production till the twenties when the Royal Commission on Agriculture provided an unusually comprehensive and insightful discussion on India's livestock economy. Thereafter, apart from one or two monographs and some discussion on the appropriate policy for cattle, there was relatively little serious work on this sector. But now the Indian livestock sector is on a high growth trajectory and currently contributes about 29.7 percent to

How to cite this article: Kumar, J., Kumar, N., Baskaur, Kumar, R. and Kumar, V. (2021). Constraints Faced by Dairy Owners in Adoption of Marketing and Scientific Dairy Practices in Haryana. Economic Affairs, 66(04): 569-575.

Source of Support: None; Conflict of Interest: None 
the agricultural gross domestic product. It is of special importance as it has strong backward and forward linkages, which promote many industries like livestock-based food processing and leather industries. The development of livestock sector will not only increase its share in the agricultural and national GDP but will also assist the sector in becoming one of the major foreign exchange earners in the Indian economy in the near future. This is strengthened by the fact that India has 512.05 million livestock (largest) and 851.81 million poultry and produce annually approximately 187.75 million tons of milk (highest in the world) and 113 billion eggs (third position in world) and is a leading producer of many of the livestock products (Department of animal husbandry, dairying and fisheries of India, 2019). These advantages if leveraged optimally can push India to the position of a leading animal products supplier of the world. But the major thrust of livestock development strategy in India has been on achieving self-sufficiency in livestock products through import substitution. However, the policy initiatives triggered in 1991 were reoriented towards improving growth and efficiency in livestock production and processing and integration with the world economy.

Haryana occupies a significant position on the animal husbandry map of India. The per capita availability of milk in Haryana was 1055 against $394 \mathrm{gm}$ per day in the country in 2018-19 (Ministry of Agriculture and Farmers Welfare, 2019). Among the farm animals cattle and buffaloes occupy the most pre-dominant place and constitute about 27.11 and 61.41 per cent, respectively, of the state's total livestock population. In Haryana, Sirsa district occupies the first position with 12.20 per cent of cattle population, while district Hisar has the highest contribution in buffalo population which is 9.94 per cent of the state (20 th Livestock Census, 2019). Increasing the income and employment of marginal and small farmers and landless agricultural labour house-holds through dairying is in conformity with the national objectives.

Keeping in view the importance of livestock sector in the State's economy, the present study was taken up to work out the various constraints (such as production, breeding, feeding, management, health care services, institutional and marketing etc.) inhibiting the development of cattle and buffalo husbandry in the state.

\section{MATERIALS AND METHODS}

The present investigation was carried out in Sirsa and Hisar districts of Haryana state as both districts of the State form important tract for the famous Haryana breed of cattle and Murrah breed of buffaloes, and dominate the livestock sector with higher density and better infrastructure were selected purposively for this study. The multistage stratified random sampling technique was used for selection of the respondents. Further two tehsil were selected Sirsa and Hisar, respectively, two villages were selected from each tehsil and 50 farmers were selected from each village (Sikanderpur \& Gudia Khera from Sirsa tehsil and Kaluwas and Chikanwas from Hisar tehsil respectively). Total 200 respondents were selected from both the districts. Primary data were collected from the sample households on well-structured and pre-tested interview schedule for the year 2019-20. The constraints score of each respondent as well as of all the respondents for each item pertaining to breeding, feeding, management, calf management and health care practices was worked out. The mean score and rank order were also computed. Following formula was employed to calculate mean per cent score.

$$
\begin{aligned}
& \text { Mean Per cent Score }= \\
& \frac{\text { Mean of item }(\text { constraint }) \text { for all responses }}{\text { Maximum score of the item }(\text { constraint })} \times 100
\end{aligned}
$$

\section{RESULTS AND DISCUSSION}

\section{Constraints perceived by farmers regarding scientific dairy farming practices}

To ascertain the factors inhibiting the development of cattle and buffalo husbandry in the state, the constraints perception of farmers were documented. The constraints hindering the adoption of recommended cattle and buffalo husbandry practices were divided into six broad areas and discussed accordingly in the following sections:

Over-all constraints perception of the farmers in all the six identified areas were assessed in the table 1. Farmers of Sirsa district perceived feeding 
Table 1: Activity wise constraints perceived by dairy owners

\begin{tabular}{lllllll}
\hline \multirow{2}{*}{ Items/Aspects } & \multicolumn{3}{c}{ Sirsa } & \multicolumn{3}{c}{ Hisar } \\
\cline { 2 - 7 } & MS* & MPS* & RO $^{*}$ & MS $^{*}$ & MPS $^{*}$ & RO $^{*}$ \\
\hline Breeding & 0.94 & 31.33 & IV & 0.95 & 31.67 & VI \\
Feeding & 1.17 & 39.00 & I & 1.23 & 41.00 & II \\
Management & 1.03 & 34.33 & III & 1.21 & 40.33 & III \\
Health care & 0.91 & 30.33 & V & 1.09 & 36.33 & V \\
Institutional & 0.89 & 29.67 & VI & 1.13 & 37.67 & IV \\
Marketing & 1.07 & 35.67 & II & 1.30 & 43.33 & I \\
\hline
\end{tabular}

*Where MS = Mean score; MPS = Mean per cent score; $R O=$ Rank order .

Table 2: Scientific breeding practices constraints perceived by dairy owners

\begin{tabular}{|c|c|c|c|c|c|c|c|}
\hline \multirow{2}{*}{ S1. No. } & \multirow{2}{*}{ Items/Aspects } & \multicolumn{3}{|c|}{ Sirsa } & \multicolumn{3}{|c|}{ Hisar } \\
\hline & & MS & MPS & RO & MS & MPS & RO \\
\hline $\mathrm{i}$ & $\begin{array}{l}\text { Non availability/inadequate artificial insemination } \\
\text { (A.I.) facilities }\end{array}$ & 0.61 & 20.33 & XIV & 0.54 & 18.00 & $\mathrm{XV}$ \\
\hline ii & A.I. centers distantly located & 0.84 & 28.00 & XI & 0.87 & 29.00 & IX \\
\hline iii & Poor quality semen & 1.11 & 37.00 & VI & 0.85 & 28.33 & $\mathrm{X}$ \\
\hline iv & Poor conception rate through A.I. & 1.28 & 42.67 & III & 1.02 & 34.00 & VIII \\
\hline $\mathrm{v}$ & Problems of repeat breeding & 1.34 & 44.67 & I & 1.11 & 37.00 & IV \\
\hline vi & Lack of A.I. facility on holidays & 1.31 & 43.67 & II & 1.61 & 53.67 & II \\
\hline vii & Use of non-descriptive bulls by the farmers & 1.15 & 38.33 & V & 1.10 & 36.67 & V \\
\hline viii & Exorbitant charges for exotic bull & 0.94 & 31.33 & IX & 0.84 & 28.00 & XII \\
\hline ix & High charges for A.I facility & 1.19 & 39.67 & IV & 1.63 & 54.33 & I \\
\hline $\mathrm{x}$ & Delayed response of reproductive disorders to V.S. & 1.03 & 34.33 & VII & 1.02 & 34.00 & VII \\
\hline xi & $\begin{array}{l}\text { Inadequate knowledge to detect heat signs in } \\
\text { bovines }\end{array}$ & 1.01 & 33.67 & VIII & 0.69 & 23.00 & XIII \\
\hline xii & Difficulty in taking bovines to A.I. centre/hospital & 0.78 & 26.00 & XIII & 1.04 & 34.67 & VI \\
\hline xiii & Abortion problems & 0.51 & 17.00 & $\mathrm{XV}$ & 0.80 & 26.67 & XI \\
\hline xiv & $\begin{array}{l}\text { Untrained and inexperienced staff at A.I. centre/ } \\
\text { hospital }\end{array}$ & 0.38 & 12.67 & XVI & 0.33 & 11.00 & XVI \\
\hline $\mathrm{xv}$ & Lack of exotic breeding bulls & 0.83 & 27.67 & XII & 1.31 & 43.67 & III \\
\hline xvi & Lack of knowledge regarding silent heat & 0.88 & 29.33 & $\mathrm{X}$ & 0.64 & 21.33 & XIV \\
\hline
\end{tabular}

constraints as most serious, whereas, the farmers of Hisar district considered marketing as most serious. Further, institutional constraints were regarded as least serious by the farmers of Sirsa district. On the other hand farmers of Hisar district rated breeding constraints as least serious.

\section{Constraints pertaining to adoption of scientific breeding practices}

Sixteen different constraints pertaining to adoption of breeding practices were identified and the farmers' response on a three point continuum was recorded. The results so obtained are presented in the table 2. As can be seen, the constraints perception of farmers varied amongst the different categories. In general, farmers' perceived problems of repeat breeding (44.67\%) lack of Artificial Insemination (A.I.) facility on holidays $(43.67 \%)$ and poor conception rate $(42.67 \%)$ as most serious constraints in Sirsa district. On the other hand, high charges for A.I facility (54.33\%), lack of A.I. facility on holidays (53.67\%) and lack of exotic breeding bulls $(43.67 \%)$ were perceived as most serious constraints by the farmers of Hisar district. It is pertinent to mentioned here that the constraint perception of farmers of Sirsa and Hisar varied significantly with regard to problems to repeat breeding and poor conception rate with AI. This difference in constraints perception may be due to different success rate of artificial insemination (AI) in cattle and buffalo. As pointed out earlier there is a need to re-look holistically at AI services in 
buffaloes. Another noteworthy observation is that reach of AI facilities has extended, by and large, to the satisfaction of farmers. Similar results were obtained by Singh and Chauhan, 2006 and Bardhan, et al. 2005 in their, respective, studies.

\section{Constraints pertaining to scientific feeding practices}

Fifteen constraints were identified in the area of feeding practices. The farmers of ( Sirsa and Hisar varied in their opinion regarding scientific feeding practices (Table 3). Farmers of both the districts ranked lack of credit facility for the purchase of feed and fodder (48.33\% Sirsa and $56.67 \%$ Hisar) as number one constraints in term of serious. Similarly, high cost of cakes / concentrates was found to be second most serious constraint (47.67\% and 54.00\%) for both the district which hinders the adoption of scientific dairy farming practices. Joshi et al. (2018) also found the same constraints in his study.

Decreasing availability of pasture land is a wellknown fact. With the increasing human population and agricultural intensification there has been a progressive decline in the availability of common pasture land. However, high cost of cakes/ concentrate inhibiting the optimum production of dairy animal is worrisome. The prices of cereals and other concentrates shot up since the data was collected. This in turn means that the farmers might be finding it difficult to manage the concentrate requirements of dairy animals in the present scenario. It is suggested here that there is a need to subsidize the cattle feed (with quality assurance) if any increase in production is to be brought about in the near future.

Surprisingly, non-availability of branded compounded feed (27.67\% Sirsa) and lack of clean drinking water for milch animals (18.67\% Hisar) were perceived to be less serious. High cost of feed and fodder and poor resources for raising fodder crops, high cost of mineral mixture, etc. have earlier been reported by Singh and Chauhan, 2006 and Dhindsa, et al. 2014

\section{Constraints pertaining to scientific management practices}

The results of the constraints pertaining to scientific management practices are summarized in table 4

Table 3: Scientific feeding practices constraints perceived by dairy owners

\begin{tabular}{|c|c|c|c|c|c|c|c|}
\hline \multirow{2}{*}{$\begin{array}{l}\text { S1. } \\
\text { No. }\end{array}$} & \multirow{2}{*}{ Items/Aspects } & \multicolumn{3}{|c|}{ Sirsa } & \multicolumn{3}{|c|}{ Hisar } \\
\hline & & MS & MPS & RO & MS & MPS & RO \\
\hline i & $\begin{array}{l}\text { Non availability/ inadequate availability of } \\
\text { green fodder }\end{array}$ & 0.96 & 32.00 & XIV & 0.85 & 28.33 & XIV \\
\hline ii & High cost of dry fodder & 1.27 & 42.33 & VI & 1.59 & 53.00 & III \\
\hline iii & Non availability of pasture & 1.27 & 42.33 & IV & 1.58 & 52.67 & IV \\
\hline iv & High cost of cakes / concentrates & 1.43 & 47.67 & II & 1.62 & 54.00 & II \\
\hline $\mathrm{v}$ & $\begin{array}{l}\text { Lack of knowledge about scientific feeding } \\
\text { practices }\end{array}$ & 1.15 & 38.33 & $\mathrm{X}$ & 1.28 & 42.67 & VIII \\
\hline vi & $\begin{array}{l}\text { Constrained feeding of milch animals due to } \\
\text { paucity of funds }\end{array}$ & 1.18 & 39.33 & IX & 1.32 & 44.00 & VII \\
\hline vii & Non availability of HYV fodder seeds. & 1.18 & 39.33 & VIII & 0.91 & 30.33 & XIII \\
\hline viii & $\begin{array}{l}\text { Non availability of supplement feeds / mineral } \\
\text { mixture. }\end{array}$ & 1.11 & 37.00 & XII & 0.97 & 32.33 & XII \\
\hline ix & $\begin{array}{l}\text { Existence of adulterated feed/ concentrates in } \\
\text { the market }\end{array}$ & 1.11 & 37.00 & XI & 1.17 & 39.00 & $x$ \\
\hline $\mathrm{x}$ & High cost of supplement feed/mineral mixture & 1.27 & 42.33 & V & 1.46 & 48.67 & VI \\
\hline xi & Non availability of branded compounded feed & 0.83 & 27.67 & $\mathrm{XV}$ & 1.04 & 34.67 & XI \\
\hline xii & Lack of clean drinking water for milch animals & 0.94 & 31.33 & XIII & 0.56 & 18.67 & $\mathrm{XV}$ \\
\hline xiii & $\begin{array}{l}\text { Lack of subsidy for compound feed and/ or } \\
\text { mineral mixture }\end{array}$ & 1.21 & 40.33 & VII & 1.56 & 52.00 & $\mathrm{~V}$ \\
\hline xiv & $\begin{array}{l}\text { Lack of credit facility for the purchase of feed } \\
\text { and fodder }\end{array}$ & 1.45 & 48.33 & I & 1.70 & 56.67 & I \\
\hline $\mathrm{xv}$ & $\begin{array}{l}\text { Inadequate/ no area for fodder cultivation due } \\
\text { to small size of operational holding }\end{array}$ & 1.35 & 45.00 & III & 1.21 & 40.33 & IX \\
\hline
\end{tabular}


Table 4: Scientific management practices constraints perceived by dairy owners

\begin{tabular}{|c|c|c|c|c|c|c|c|}
\hline \multirow{2}{*}{ S1. No. } & \multirow{2}{*}{ Items/Aspects } & \multicolumn{3}{|c|}{ Sirsa } & \multicolumn{3}{|c|}{ Hisar } \\
\hline & & MS & MPS & RO & MS & MPS & RO \\
\hline $\mathrm{i}$ & Inadequate / unscientific housing system & 1.29 & 43.00 & III & 1.49 & 49.67 & IV \\
\hline ii & High cost of raw materials for construction of cattle shed & 1.38 & 46.00 & II & 1.60 & 53.33 & II \\
\hline iii & Lack of knowledge about modest scientific housing & 1.25 & 41.67 & IV & 1.49 & 49.67 & III \\
\hline iv & Lack of subsidy for construction of scientific housing & 1.53 & 51.00 & I & 1.72 & 57.33 & I \\
\hline $\mathrm{v}$ & Inadequate time devotion for animal management & 1.08 & 36.00 & VI & 0.96 & 32.00 & VIII \\
\hline vi & Improper sanitation and hygiene in the cattle shed & 1.14 & 38.00 & V & 1.41 & 47.00 & $\mathrm{~V}$ \\
\hline vii & Absence of keeping milk production and other dairy records & 0.74 & 24.67 & VIII & 1.31 & 43.67 & VI \\
\hline viii & $\begin{array}{l}\text { Lack of training facilities about scientific bovines' management at the } \\
\text { farmers door step }\end{array}$ & 0.79 & 26.33 & VII & 1.13 & 37.67 & VII \\
\hline ix & $\begin{array}{l}\text { Dependence on permanent labour/ casual labour for milch bovines' } \\
\text { management }\end{array}$ & 0.64 & 21.33 & IX & 0.75 & 25.00 & IX \\
\hline $\mathrm{x}$ & Reluctance of family members for animal management & 0.61 & 20.33 & $\mathrm{x}$ & 0.60 & 20.00 & $\mathrm{X}$ \\
\hline
\end{tabular}

Table 5: Scientific health practices constraints perceived by dairy owners

\begin{tabular}{|c|c|c|c|c|c|c|c|}
\hline \multirow{2}{*}{ Sl. No. } & \multirow{2}{*}{ Items/Aspects } & \multicolumn{3}{|c|}{ Sirsa } & \multicolumn{3}{|c|}{ Hisar } \\
\hline & & MS & MPS & RO & MS & MPS & RO \\
\hline i & Non availability of veterinary hospital at farmers door step & 1.15 & 38.33 & IV & 1.45 & 48.33 & IV \\
\hline ii & High cost of treatment & 1.31 & 43.67 & II & 1.55 & 51.67 & II \\
\hline iii & $\begin{array}{l}\text { Lack of awareness about the Govt. services and facilities for health } \\
\text { care }\end{array}$ & 1.16 & 38.67 & V & 1.33 & 44.33 & VI \\
\hline iv & Inadequate / untimely supply of vaccines & 0.71 & 23.67 & VIII & 0.78 & 26.00 & VIII \\
\hline $\mathrm{v}$ & Untimely adoption of vaccination facilities & 0.83 & 27.67 & VII & 0.82 & 27.33 & VII \\
\hline vi & Non availability of veterinary doctors in odd hours/ holidays & 1.09 & 36.33 & VI & 1.49 & 49.67 & III \\
\hline vii & Lack of veterinary medical store & 1.47 & 49.00 & I & 1.70 & 56.67 & I \\
\hline viii & Inadequate/ lack of funds for treatment of animals & 1.30 & 43.33 & III & 1.38 & 46.00 & $\mathrm{~V}$ \\
\hline
\end{tabular}

for Sirsa and Hisar districts. As can be expected, lack of subsidy for construction of scientific housing (51.00\% Sirsa and $57.33 \%$ Hisar) was perceived most serious by farmers of both the districts. This calls for alternative low cost housing technology generation. On the other side, reluctance of family members for animal management $(20.33 \%$ Sirsa and $20.00 \%$ Hisar) was perceived to be least serious by both the districts. Lack of training facilities about scientific management was also perceived less serious. This perhaps is an indicator of higher degree of satisfaction with present state of affairs. Any future extension programme must, therefore, include the creation of dissonance with the present as an important aspect. Similar trend were reported by Kumar (2015) and Shaikh, et al. (2013).

\section{Constraints pertaining to scientific healthcare practices}

Constraints regarding scientific healthcare practices are presented in table 5 . Lack of veterinary medical store $(49.00 \%$ Sirsa and $56.67 \%$ Hisar) was perceived as most serious constraint by farmers. On the other hand, inadequate/untimely supply of vaccines (23.67\% Sirsa and $26.00 \%$ Hisar) was considered less serious by farmers. This perhaps is an indicator of improving healthcare delivery system. Never the less, it is suggested that low cost alternative treatment regimens should be developed to expedite the spread of appropriate healthcare practices adoption. Lack of facilities for treatment, vaccines and medicines, high cost of treatment, lack of veterinary dispensaries and poor knowledge have earlier been reported as constraints in dairy development by Singh and Chauhan (2006).

\section{Constraints pertaining to Institutional}

The results of the institutional constraints perceived by farmers are summarized in table 6 . It was found that people still prefer natural mating as observed during data collection and hence that the majority of farmers considered non-availability of 
Table 6: Institutional constraints perceived by dairy owners

\begin{tabular}{|c|c|c|c|c|c|c|c|}
\hline \multirow{2}{*}{ S1. No } & \multirow{2}{*}{ Items/Aspects } & \multicolumn{3}{|c|}{ Sirsa } & \multicolumn{3}{|c|}{ Hisar } \\
\hline & & MS & MPS & RO & MS & MPS & RO \\
\hline i & $\begin{array}{l}\text { Non availability of cooperative feed manufacturing } \\
\text { unit }\end{array}$ & 0.78 & 26.00 & V & 1.11 & 37.00 & IV \\
\hline ii & $\begin{array}{l}\text { Lack of farmers voluntary organization to manufacture } \\
\text { cattle feed }\end{array}$ & 0.45 & 15.00 & VI & 0.77 & 25.67 & VI \\
\hline iii & Defunct milk procurement cooperative society & 0.87 & 29.00 & III & 0.97 & 32.33 & V \\
\hline iv & Lack of milk procurement cooperative society & 1.16 & 38.67 & II & 1.42 & 47.33 & II \\
\hline $\mathrm{v}$ & $\begin{array}{l}\text { Non availability of quality breeding bulls through } \\
\text { village Panchayat }\end{array}$ & 1.42 & 47.33 & I & 1.43 & 47.67 & I \\
\hline vi & $\begin{array}{l}\text { Lack of voluntary organization for milch animals } \\
\text { trading }\end{array}$ & 0.86 & 28.67 & IV & 1.21 & 40.33 & III \\
\hline
\end{tabular}

Table 7: Marketing constraints perceived by dairy owners

\begin{tabular}{|c|c|c|c|c|c|c|c|}
\hline \multirow{2}{*}{$\begin{array}{l}\text { S1. } \\
\text { No. }\end{array}$} & \multirow{2}{*}{ Items/Aspects } & \multicolumn{3}{|c|}{ Sirsa } & \multicolumn{3}{|c|}{ Hisar } \\
\hline & & MS & MPS & RO & MS & MPS & RO \\
\hline i & $\begin{array}{l}\text { Lack of organized/ regulated markets for quality } \\
\text { breed }\end{array}$ & 0.76 & 25.33 & $\mathrm{~V}$ & 0.89 & 29.67 & $\mathrm{~V}$ \\
\hline ii & $\begin{array}{l}\text { Inadequate market intelligence for marketing of } \\
\text { bovines }\end{array}$ & 0.44 & 14.67 & VIII & 0.86 & 28.67 & VII \\
\hline iii & $\begin{array}{l}\text { Defunct milk producers' cooperative society for } \\
\text { milk procurement }\end{array}$ & 0.49 & 16.33 & VII & 0.94 & 31.33 & IV \\
\hline iv & $\begin{array}{l}\text { Improper monitoring of milk producers } \\
\text { cooperative society }\end{array}$ & 1.14 & 38.00 & III & 1.22 & 40.67 & III \\
\hline $\mathrm{v}$ & Lack of minimum support price for milk & 1.73 & 57.67 & I & 1.89 & 63.00 & I \\
\hline vi & Problem of milk transportation to the market & 1.40 & 46.67 & II & 1.32 & 44.00 & II \\
\hline vii & $\begin{array}{l}\text { Lack of referegerational facilities at cooperative } \\
\text { societies }\end{array}$ & 0.61 & 20.33 & VI & 0.79 & 26.33 & VIII \\
\hline viii & $\begin{array}{l}\text { Inadequate/ lack of cooperative milk procurement } \\
\text { booth in the village }\end{array}$ & 0.84 & 28.00 & IV & 0.90 & 30.00 & VI \\
\hline
\end{tabular}

quality breeding bulls through village Panchayats $(47.33 \%$ and $47.67 \%)$ the most serious constraint by the farmers of both the district. However, Government should provide quality breeding bulls to village Panchayat which will help to increase milk yield. Lack of farmers voluntary organization to manufacture cattle feed $(15.00 \%$ Sirsa and $25.67 \%$ Hisar) was found to be the less serious constraint in adoption of marketing and scientific dairy practices. Villagers can form their own small groups and milk pool which can be transported to nearest milk collection centre. This will significantly reduce the transportation costs. However, such an action is difficult to come by own. Similarly, Yadav et al. (2007) and Kushram (2018) had earlier reported inadequate credit availability, high interest rate, bank loan problems, unawareness regarding loans, commission to middlemen and agents as constraints affecting adoption of dairy technologies.

\section{Constraints pertaining to marketing}

Constraints pertaining to marketing are presenting in table 7. Lack of minimum support price for milk (57.67\% Sirsa and $63.00 \%$ Hisar) was considered as most serious constraints by farmers of both the districts. Inadequate market intelligence for marketing of bovines (14.67\%) was considered less serious constraints by farmers of Sirsa district, while farmers of Hisar district perceived lack of referegerational facilities at cooperative societies $(26.33 \%)$ as the least serious constraint adoption of dairy farming practices.

It is, therefore, suggested that adequate infrastructural investment to create transportation system should be made that will facilitate development of appropriate marketing opportunity to all the rural areas and will thus act as an incentive for higher production. Secondly, with the increasing demand of milk in the 
past few years, the need for minimum support price is automatically done away with; such increases in demand are already fuelling the prices of milk. Such a high rise in price of milk has in fact become a problem these days, as the adulteration business has become highly profitable. What is needed is that the marketing infrastructure in terms of modern supply chain be significantly expanded to meet consumer needs and provide adequate incentive to the rural milk producers. Lower price of milk and high cost of production has earlier been reported as major constraints Bardhan, et al. 2005. Singh and Chauhan, 2006 and Kumar et al. 2006.

\section{CONCLUSION}

Farmers of Sirsa district perceived feeding constraints as most serious whereas the farmers of Hisar considered marketing constraints as most serious indicating significant differences perhaps owing to agro-climatic variations. Problems of repeat breeding and high charges for A.I facility as most serious constraints in Sirsa and Hisar districts, respectively. lack of credit facility for the purchase of feed and fodder, lack of subsidy for construction of scientific housing, lack of veterinary medical store, non-availability of quality breeding bulls through village Panchayats and lack of minimum support price for milk were found most serious constraints in both the districts. Almost all the farmers across different categories considered high cost of treatment as serious constraints in adoption of marketing and scientific dairy farming practices thus underlining the need to develop low cost treatment regimens.

\section{ACKNOWLEDGEMENTS}

Authors wish to acknowledge Singhania University and all the farmers who participated in the study and made the study successful.

\section{REFERENCES}

Bardhan, D., Srivastava, R.S.L. and Dabas, Y.P.S. 2005.A study of constraints perceived by farmers in rearing dairy animals. Ind. J. Dairy Sc., 58(3): 214-218.

Dhindsa, S.S., Nanda, R. and Kumar, B. 2014. Problems and constraints of dairy farming in Fatehgarh Sahib district of Punjab. Progressive Research- An Int. J., 9(1): 250-252.

Joshi, P., Tiwari, R., Singh, P.K. and Dutt, T. 2018. Preferences, suggestions and constraints faced by badri cattle owners while rearing badri cattle in hills of Uttarakhand. Int. J. Cur. Microb. Appl. Sc., 7(Spl. Iss.): 4617-4626.

Kumar, M. 2015. Constraints encountered in the buffalo rearing by the farmers in breeding tract of Nili-Ravi. Asian J. of Anim. Sc., 10(1): 85-87.

Kumar, S.R., Jagadeeswary, V. and Sasidhar, P.V.K. 2006. Constraints in adoption of dairy production technologies. Indian Vet. J., 83(2): 185-186.

Kushram, P., Singh, R. and Gour, A. K. 2018. Constraint faced by cattle owners in adoption of scientific cattle farming practices. Global J. of Bio-Science and Biotech., 7(1): 24-26.

Shaikh, J.I., Tekale, V.S. and Kale, R.A. 2013. Constraints experienced by dairy farmers in management of dairy enterprise. Agric. Update, 8(4): 623-625.

Singh, M. and Chauhan, A. 2006. Constraints faced by dairy owners in adoption of scientific dairy practices. Ind. J. Dairy Sc., 59(1): 49-51.

Yadav, S.P., Yadav, M.P.S., Singh O. and Yadav, R.N. 2007. Constraints analysis in adoption of dairy technology. Progressive Research- An. Int. J., 2(1/2): 167. 
